\title{
Growth in Potato Production: A Zone Wise Analysis in Eastern Uttar Pradesh, India
}

\author{
Ekta Pandey*, V.N. Rai, Neeraj Singh and Piyush Kumar Singh
}

Department of Agricultural Statistics, College of Agriculture, Narendra Dev University of Agriculture and Technology, Kumarganj-Faizabad (UP), 224-229, India

*Corresponding author

\section{A B S T R A C T}

Keywords

Potato, Agro-climatic

zones, Graphical analysis,

Linear Growth Rate (LGR)

Compound growth rate

(CGR), Instability index

Article Info

Accepted:

18 April 2018

Available Online:

10 May 2018
The paper analyses the growth and instability in terms of area, production and productivity of potato in Eastern Uttar Pradesh. The growth was examined by Compound growth rate and Simple growth rate. The study relates to 1980-81 to 2014-15 which is further divided into four subperiods. The area under potato registered positive growth rate throughout the period in Vindhyan Zone. The productivity of potato was found to be highest in North Eastern Plain Zone where as lowest in Eastern Plain Zones.

\section{Introduction}

Agriculture in India has a significant history. Today India ranks second worldwide in farm output. India has shown a steady average nationwide annual increase in the kilograms produced per hectare for various agricultural items, over the last 60 years. These gains have come mainly from India's green revolution, improving road and power generation infrastructure, knowledge of gains and reforms. The state is divided into 9 agroclimatic zones - Tarai Region, Western Plain Region, Central Western Region, South Western Region, Central Plain Region, Bundelkhand Region, North Eastern Plain
Region, Eastern Plain Region and Vindhyachal Region. The study relates to the Eastern Uttar Pradesh which covered different three Agro- climatic zones viz. North Eastern Plain Zone, Eastern Plain Zone, and Vindhyan Zone. North Eastern Plain Zone constitute 11 districts viz. Basti, Bahraich, Balrampur, Deoria, Gorakhpur, Gonda, Mahrajganj, Kushinagar, Siddhartha Nagar, Sant Kabir Nagar and Shravasti. Eastern Plain Zone constitute 11 Districts viz. Azamgarh, Ambedkar Nagar, Barabanki, Ballia, Chandauli, Faizabad, Ghazipur, Mau, Jaunpur, Sultanpur, and Varanasi. In Vindhyan Zone constitutes three districts viz. Mirzapur, Sonbhadra, and Sant Ravidas Nagar.

In the agro-climatic zones of eastern Uttar 
Pradesh we study about the crop: Potato. The Potato is starchy, tuberous crop from the perennial nightshade Solanum tuberosum. Potato may be applied to both the plant and the edible tuber. Potato has become staple food in many parts of the world and an integral part of much of the world's food supply. Potatoes are the world's fourth- largest food crop.

The potato was first domesticated in the region of modern- day southern Peru and extreme north western Bolivia between 8000 and $5000 \mathrm{BC}$. It has since spread around the world and become a staple crop in many countries. Raw potato is $79 \%$ water, $17 \%$ carbohydrates, $2 \%$ protein, contains negligible fat. In a 100 grams amount, raw potato provides 322 kilojoules and is a rich source of vitamin $\mathrm{B} 6$ and vitamin $\mathrm{C}$.

In 2014, world production of potatoes was 382 million tonnes, an increase of $4 \%$ over 2013 amounts and led by china with $25 \%$ of the world total. Other major producers were India, Russia, Ukraine and the United states.

\section{Materials and Methods}

This paper deals with materials and statistical methodologies to carry out the investigation undertaken. In order to study the trend and growth rate of area, production and productivity of Potato crop in Eastern Uttar Pradesh, some appropriate statistical methodologies have been used. These statistical methodologies are systematically described here.

The time series data pertaining to the period from 1980-81 to 2014-15 on area, production and productivity of different crops have been used to study the growth trends. These time series data have been procured from the Bulletins of Directorate of Agricultural Statistics and Crop-Insurance, Krishi Bhawan,
Lucknow, Government of Uttar Pradesh.

\section{Estimation of growth rate}

Linear growth rate (LGR) and compound growth rate (CGR) were used for the estimation of growth rates in crop characteristics i.e., area, production and productivity in different zones of Eastern Uttar Pradesh, India.

\section{By linear function}

Linear function is given by the equation:

$X_{t}=a t+b$

Where,

$\mathrm{t}$ is the time in years, independent variable $\mathrm{X}_{\mathrm{t}}$ is the trend value of the dependent variable $\mathrm{a}$ and $\mathrm{b}$ are constants

The above equation is fitted by using the least squares method of estimation.

The linear growth rate is calculated by the formula:

Linear growth rate $($ LGR $\%)=\frac{\frac{b}{\bar{y}} \times 100}{}$

\section{By compound function}

Compound function is given by the equation:

$X_{t}=a b^{t}$

$\log X_{t}=\log a+t \log b$

Where,

$\mathrm{X}_{\mathrm{t}}$ is the characteristic (area, production or productivity of dependent variable)

$\mathrm{t}$ is the time in years, independent variable $\mathrm{a}$ is intercept 
$\mathrm{b}$ is regression coefficient.

The ' $a$ ' and ' $b$ ' are calculated by applying the method of Least Squares.

Finally the compound growth rates were worked out as described below:

Compound growth rate: CGR $(\%)=($ antilog $\mathrm{b}$ - 1) x 100

\section{Measure of instability in potato production}

The level of instability in the area, production and productivity of potato crop will be estimated using suitable statistical tools. Generally the coefficient of variation is used to measure the extent of instability. However, the simple coefficients of variation (C.V.) often contain the trend component and thus overestimate the level of instability in time series data characterized by long term trend. To overcome this problem, a measure of instability is estimated by using Cuddy Della Valle Index which corrects the coefficient of variations and it is given by

Instability index $=\mathrm{cv} \sqrt{1-\mathrm{R}^{2}}$

Where, $\mathrm{R}^{2}$ is the coefficient of determination from a time trend regression adjusted by the number of degree of freedom.

\section{Results and Discussion}

The area under Potato has increased at the rate of about 1.43 per cent since 1981- 95 onwards. The increase in growth rate was prominent during the annual period i.e. 0.48 per cent as compared to 0.13 and 0.07 per cent during second and third period, respectively.

In the case of production, it has increased at the rate of about 1.22 per cent annually during the entire period under study. A high growth rate in the production of potato has been found 2.01 per cent during second period as compared to -0.30 and 0.10 per cent during the first and third period, respectively.

Graph.1 Zone-wise production of potato in Eastern Uttar Pradesh over 3 year moving average

(1980-81 to 2014-15)

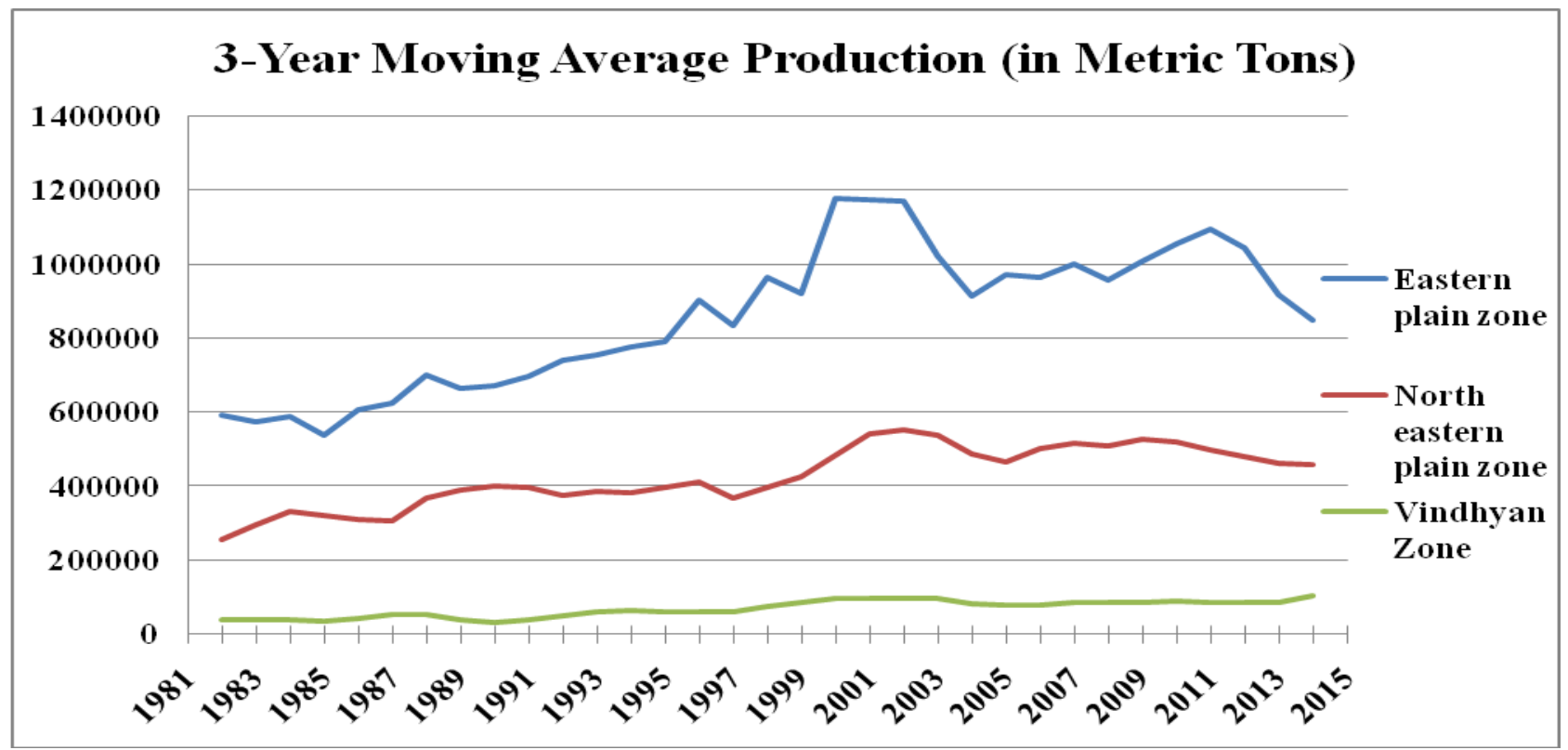


Graph.2 Zone-wise area of potato in Eastern Uttar Pradesh over 3 year moving average (1980-81 to 2014-15)

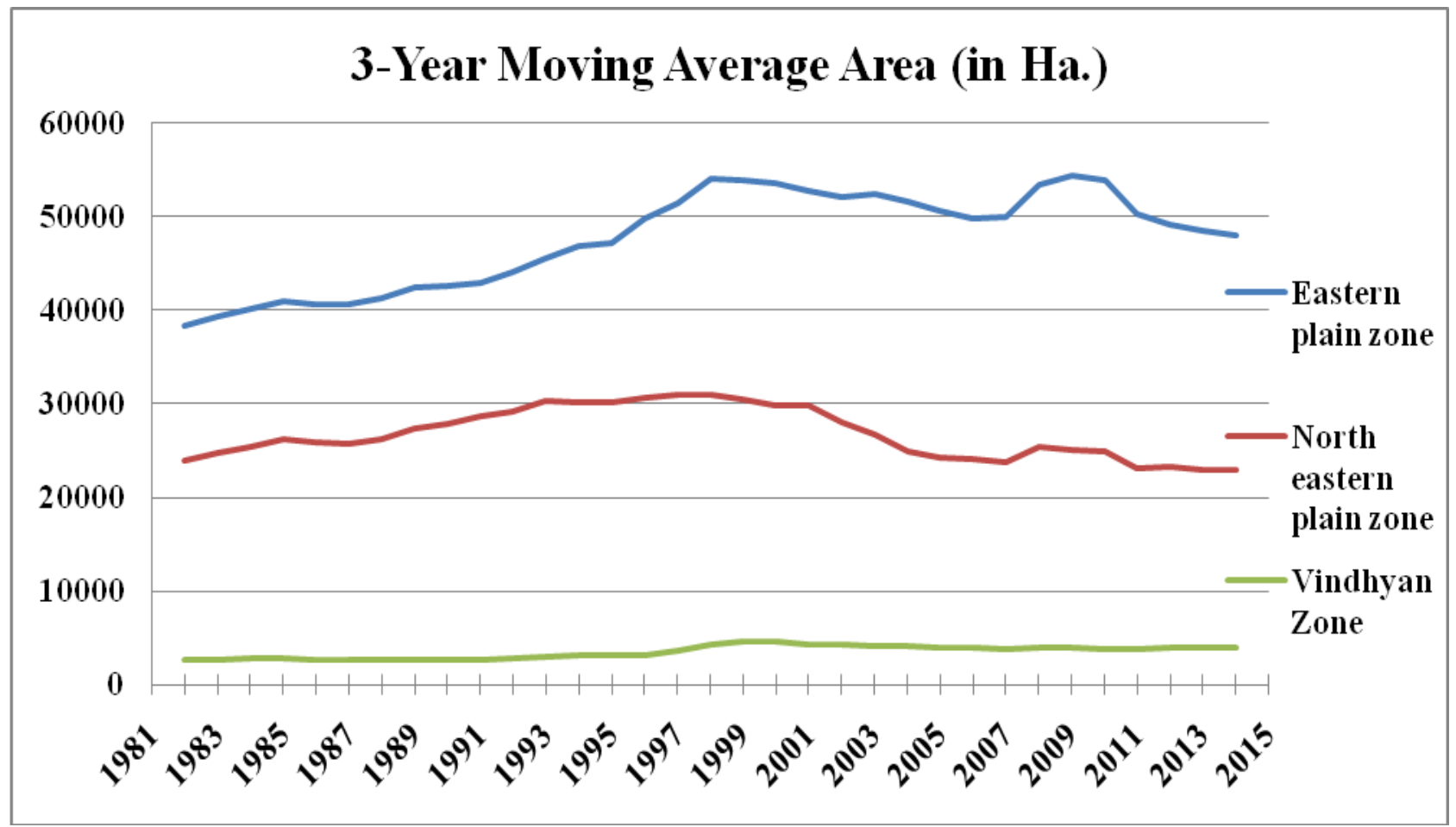

Graph.3 Zone-wise productivity of potato in Eastern Uttar Pradesh over 3 year moving average (1980-81 to 2014-15)

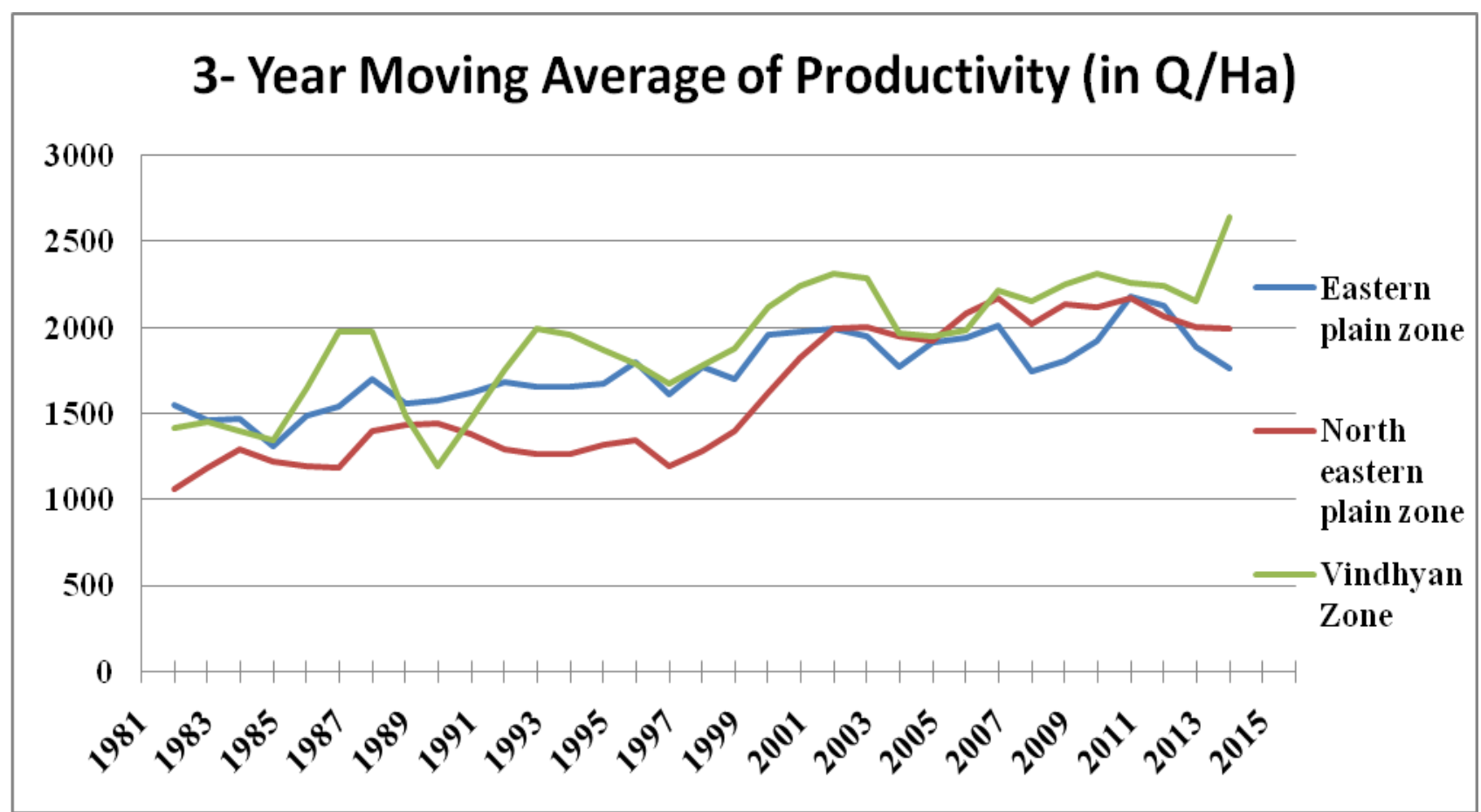


Table.1 SGR \& CGR of area, production and productivity of potato during different periods in Eastern plain zone

\begin{tabular}{|r|l|c|c|c|}
\hline \multirow{2}{*}{ Period } & & Area & Production & Productivity \\
\hline \multirow{2}{*}{$\mathbf{1 9 9 5 - 9 6}$ to to $\mathbf{1 9 9 4 - 9 5}$} & S.G.R & 1.32 & -0.53 & -2.02 \\
\hline & C.G.R & 1.43 & -0.30 & -1.68 \\
\hline \multirow{2}{*}{$\mathbf{2 0 0 5 - 0 6}$ to $\mathbf{2 0 1 4 - 1 5}$} & S.G.R & 0.14 & 1.88 & 1.87 \\
\hline & C.G.R & 0.13 & 2.01 & 1.95 \\
\hline & S.G.R & 0.07 & 0.11 & 0.15 \\
\hline \multirow{2}{*}{$\mathbf{1 9 8 0 - 8 1}$ to $\mathbf{2 0 1 4 - 1 5}$} & C.G.R & 0.07 & 0.10 & 0.13 \\
\hline & S.G.R & 0.41 & 1.14 & 0.50 \\
\hline & C.G.R & 0.48 & 1.22 & 0.59 \\
\hline
\end{tabular}

Table.2 SGR \& CGR of area, production and productivity of during potato different periods in North Eastern plain zone

\begin{tabular}{|c|c|c|c|c|}
\hline \multicolumn{2}{|l|}{ Period } & Area & Production & Productivity \\
\hline \multirow[t]{2}{*}{$1980-81$ to $1994-95$} & S.G.R & 1.87 & 2.98 & 2.64 \\
\hline & C.G.R & 1.88 & 3.16 & 4.72 \\
\hline \multirow[t]{2}{*}{ 1995-96 to 2004-05 } & S.G.R & -2.88 & 4.93 & 7.84 \\
\hline & C.G.R & -2.91 & 5.31 & 8.52 \\
\hline \multirow[t]{2}{*}{$2005-06$ to $2014-15$} & S.G.R & -1.27 & -1.98 & -0.61 \\
\hline & C.G.R & -1.26 & -1.99 & -0.61 \\
\hline \multirow[t]{2}{*}{$1980-81$ to $2014-15$} & S.G.R & -0.36 & 1.71 & 2.20 \\
\hline & C.G.R & -0.37 & 1.83 & 2.23 \\
\hline
\end{tabular}

Table.3 SGR \& CGR of area, production and productivity of potato during different periods in Vindhyan zone

\begin{tabular}{|c|c|c|c|c|}
\hline \multicolumn{2}{|l|}{ Period } & Area & Production & Productivity \\
\hline \multirow[t]{2}{*}{$1980-81$ to $1994-95$} & S.G.R & 4.44 & 6.85 & 2.15 \\
\hline & C.G.R & 3.28 & 5.33 & 2.09 \\
\hline \multirow[t]{2}{*}{ 1995-96 to 2004-05 } & S.G.R & 0.46 & 3.94 & 3.52 \\
\hline & C.G.R & 0.56 & 4.50 & 3.71 \\
\hline \multirow[t]{2}{*}{$2005-06$ to $2014-15$} & S.G.R & 0.11 & 1.66 & 1.49 \\
\hline & C.G.R & 0.11 & 1.56 & 1.41 \\
\hline \multirow[t]{2}{*}{$1980-81$ to $2014-15$} & S.G.R & 1.18 & 2.50 & 1.55 \\
\hline & C.G.R & 1.45 & 3.09 & 1.62 \\
\hline
\end{tabular}

Table.4 Instability index (in \%) of potato during 1980-81 to 2014-15

\begin{tabular}{|c|c|c|c|}
\hline Zones & Area & Production & Productivity \\
\hline North Eastern Plain Zone & 9.40 & 9.85 & 10.39 \\
\hline Eastern Plain Zone & 10.73 & 13.07 & 13.61 \\
\hline Vindhyan Zone & 19.50 & 31.11 & 18.55 \\
\hline
\end{tabular}

The productivity of potato has also increased at the rate of about 0.59 per cent annually since 1980-81to 2014-15 onwards. A high growth rate of about 1.95 per cent was observed during the second period. 
The area under Potato has increased at the rate of about 1.88 per cent since 1981- 95 onwards. The decreased in growth rate was prominent during the annual period i.e. -0.37 per cent as compared to -2.91 and -1.26 per cent during second and third period, respectively. A positive annual growth rate of 5.31 per cent for production has been obtained during second period. While productivity has increased at the rate of 8.52 per cent during the second period.

The area has registered positive growth rate in all the four periods. The area under potato has increased at the rate of about 3.28 per cent in first period. Like that production and productivity has also increased at the rate of 5.33 in first period and 3.71 in second period.

The table 4 shows that the instability is low in case of area under potato as compared to production and productivity in all the three zones. The instability in production and productivity was found to be high in Vindhyan Zone as compared to North Eastern Plain Zone and Eastern Plain Zone. sIn Vindhyan Zone, high instability was observed in Potato production $(31.11 \%)$ and productivity $(18.55 \%)$ during the study period. Whereas, lowest instability in production and productivity was observed in North Eastern Plain Zone.

The time series data on area, production, and productivity of different crops in Eastern Uttar Pradesh pertaining to the period $1980-81$ to 2014-15 were used for the investigation of trend and growth of crop production and also impact of technological changes on different crop production in Eastern Uttar Pradesh. The relevant statistical tools and technique are like regression analysis, instability etc. Eastern Uttar Pradesh divided into three zones (Table 1-5).
In these zones Vindhyan Zone shows positive growth rate in all four periods. In Annual comparison of these zones Vindhyan zone has increased area, production and productivity i.e. $1.45,3.09$ and 1.62 respectively. In these three zones Vindhyan Zone is the best in there production, productivity and area. There annual value is increased in comparison of both Zones viz. North Eastern Plain Zone and Eastern Plain Zone.

\section{References}

Chandran, K. P., Pandit, A. and Pandey, N. K. (2005). Evaluation of models for estimating potato production trends in major states of India. Potato Journal, 32: 3/4, 219-220.

Kumar, S. and Taneja, N. K. (2008). Agricultural growth and performance of Uttar Pradesh: a total factor productivity analysis. Agricultural Situation in India, 65: 7, 463469.

Manvendra Singh and K. Supriya (2017) Growth Rate and Trend Analysis of Wheat Crop in Uttar Pradesh, India. Int. J. Curr. Microbiol. App. Sci, 6(7): 2295-2301.

Neeraj Singh, Piyush Kumar Singh and Shri Sunil Kumar (2018) Growth Rate of Wheat Crop in Azamgarh Division of Eastern Uttar Pradesh, India. Int.J.Curr.Microbiol.App.Sci. 7(03): 33483352 .

Prajneshu and K. P. Chandran (2005) Computation of Compound Growth Rates in Agriculture. Agricultural Economics Research Review, Vol. 18: 317-324.

Srivastava S.C., Singh, B.K., Sudeep S Tomar and Yadava, H.S (2013) Growth Pattern of Major Pulses in Eastern Uttar Pradesh. International Journal of Farm Sciences, 3(2): 1-9.

\section{How to cite this article:}

Ekta Pandey, V.N. Rai, Neeraj Singh and Piyush Kumar Singh. 2018. Growth in Potato Production: A Zone Wise Analysis in Eastern Uttar Pradesh, India. Int.J.Curr.Microbiol.App.Sci. 7(05): 2429-2434. doi: https://doi.org/10.20546/ijcmas.2018.705.279 